\title{
PERKIRAAN WISATAWAN ASING DI KALIMANTAN BARAT DENGAN METODE PEMULUSAN EKSPONENSIAL WINTER ADITIF
}

\author{
Melita
}

\section{INTISARI}

Metode pemulusan eksponensial Winter Aditif digunakan untuk mengatasi data yang mengandung pola musiman dan trend. Tujuan penelitian ini adalah untuk menganalisis metode pemulusan eksponensial winter aditif dalam memperkirakan jumlah wisatawan asing di Kalimantan Barat. Berdasarkan hasil analisis diperoleh bahwa metode pemulusan eksponensial Winter Aditif memiliki nilai MAPE sebesar 26,09\%. Sehingga metode pemulusan ekponensial Winter Aditif memiliki kemampuan ramalan yang cukup baik dalam memperkirakan jumlah wisatawan asing di Kalimantan Barat pada tahun 2018. Hasil perkiraan ramalan wisatawan asing di Kalimanatan Barat terendah terjadi pada Oktober 2018 sebanyak 1.274 orang dan tertinggi pada bulan Desember 2018 mencapai 2.711 orang.

Kata kunci:Winter Aditif, MAPE

\section{PENDAHULUAN}

Indonesia merupakan negara yang cukup luas. Indonesia yang terdiri dari banyak provinsi dengan keindahan alam dan keanekaragaman suku dan budaya, salah satunya adalah Provinsi Kalimantan Barat. Kalimantan Barat terdiri dari 14 kabupaten, yang setiap kabupatennya memiliki daya tarik tersendiri dan tempat wisata yang sangat menarik dikunjungi bagi wisatawan lokal maupun wisatawan asing. Wisatawan asing adalah orang yang melakukan perjalanan ke suatu tempat dan menetap ditempat tersebut dalam kurun waktu tertentu [1]. Peningkatan wisatawan asing setiap waktunya membuat kesulitan bagi pelaku wisata dalam memberikan pelayanan terbaik, sehingga perlu dilakukan peramalan.

Peramalan adalah ilmu untuk memprediksi peristiwa-peristiwa masa depan dengan pengambilan data historis dan memproyeksikannya ke masa depan dengan menggunakan beberapa bentuk model matematis [2]. Banyak sekali metode peramalan yang ada, misalnya Metode Moving Average, Metode Exponential Smoothing, dan Metode Dekomposisi. Metode-metode tersebut belum tentu cocok untuk setiap ramalan. Metode yang cocok untuk setiap ramalan yaitu metode yang bisa meminimumkan kesalahan [3]. Permasalahan yang dibahas pada penelitian ini adalah bagaimana memperkirakan jumlah wisatawan asing di Kalimantan Barat dengan metode pemulusan eksponensial Winter Aditif.

Tujuan pada penelitian ini adalah menganalisis metode pemulusan eksponensial Winter Aditif dalam memperkirakan banyaknya wisatawan asing di Kalimantan Barat. Batasan masalah pada penelitian ini adalah data yang digunakan merupakan data wisatawan asing yang masuk ke Kalimantan Barat melalui pos lintas batas Entikong pada Januari 2014 sampai Desember 2017. Langkah pertama yang dilakukan pada penelitian ini adalah mengumpulkan data wisatawan asing masuk ke Kalimantan Barat melalui pos lintas batas Entikong pada Januari 2014 sampai Desember 2017. Kemudian data tersebut dilihat bentuk polanya, langkah selanjutnya menganalisis data tersebut dengan metode pemulusan eksponensial Winter Aditif. Selanjutnya menghitung tingkat akurasi peramalan metode tersebut, setelah itu melakukan perkiraan jumlah wisatawan asing di Kalimantan Barat pada bulan Januari sampai Desember tahun 2018. 


\section{METODE WINTER ADITIF}

Metode pemulusan eksponensial Winter Aditif dengan penambahan musiman yang digunakan untuk varisi musiman yang bersifat konstan. Ramalan dari pemulusan eksponensial Winter Aditif dilakukan dengan tiga menentukan nilai awal pemulusan dan tiga parameter (dengan nilai antara 0 dan 1) [4]:

Pemulusan Keseluruhan

$$
S_{t}=\alpha\left(X_{t}-I_{t-L)}+(1-\alpha)\left(S_{t-1}+b_{t-1}\right)\right.
$$

Pemulusan Trend

Pemulusan Musiman

$$
b_{t}=\beta\left(S_{t}-S_{t-1}+(1-\beta) b_{t-1}\right.
$$

$$
I_{t}=\gamma\left(X_{t}-S_{t}\right)+(1-\gamma) I_{t-L}
$$

Ramalan

$$
F_{t+m}=S_{t}+b_{t} m+I_{t-L+m}
$$

dimana:

$$
\begin{aligned}
S_{t} & =\text { Nilai pemulusan eksponensial pada waktu ke- } t \\
b_{t} & =\text { Konstanta pemulusan } \\
I_{t} & =\text { Faktor penyesuaian musiman } \\
\alpha & =\text { Parameter pemulusan eksponensial untuk data }(0<\alpha<1) \\
\beta & =\text { Parameter pemulusan eksponensial untuk trend }(0<\beta<1) \\
\gamma & =\text { Parameter pemulusan eksponensial untuk musiman }(0<\gamma<1)
\end{aligned}
$$

Dalam metode pemulusan eksponensial Winter Aditif diperlukan nilai awal $\left(S_{L}, b_{L}, I_{k}\right)$ yang sangat dibutuhkan, karena peramalan untuk $t-1$ belum tersedia. Rumus yang digunakan untuk menentukan nilai awal pemulusan dengan rumus sebagai berikut [4]:

$$
\begin{aligned}
& S_{L}=\frac{1}{L}\left(X_{1}+X_{2}+\cdots+X_{L}\right) \\
& b_{L}=\frac{1}{k}\left(\frac{X_{L+1}-X_{1}}{L}+\frac{X_{L+2}-X_{2}}{L}+\cdots+\frac{X_{L+k}-X_{k}}{L}\right) \\
& I_{k}=X_{k}-S_{L}
\end{aligned}
$$

dimana:

$$
\begin{aligned}
S_{L} & =\text { Nilai awal pemulusan } \\
b_{L} & =\text { Nilai awal kecendrungan } \\
I_{k} & =\text { Nilai awal musiman } \\
L & =\text { Panjang musiman }
\end{aligned}
$$

\section{AKURASI PERAMALAN}

Ukuran keakuratan peramalan merupakan hasil perataan beberapa fungsi dari selisih nilai aktual dengan nilai peramalan atau sering disebut residual. Peramalan bertujuan mendapatkan ramalan yang bisa meminimumkan kesalahan meramal (forecast error), untuk mengukur forecast error bisa menggunakan Mean Absolute Percentage Error (MAPE) [3].

Mean Absolute Percentage Error (MAPE) yang dihitung dengan menggunakan kesalahan absolut pada tiap periode dibagi dengan nilai observasi yang nyata untuk periode tersebut, kemudian merataratakan kesalahan yang menghitung ukuran persentase penyimpangan antara data aktual dan data peramalan. Semakin kecil rata-rata persentase kesalahan maka semakin besar nilai keakuratan peramalan sebaliknya semakin besar rata-rata persentasi kesalahan maka semakin kecil nilai keakuratan 
peramalan. Rumus untuk menghitung nilai Mean Absolute percentage Error (MAPE) adalah sebagai berikut: [4]

$$
M A P E=\frac{\sum_{t=1}^{n}\left|\frac{X_{t}-F_{t}}{X_{t}}\right|}{n} \times 100 \%
$$

dimana:

$$
\begin{aligned}
X_{t} & =\text { Nilai aktual } \\
F_{t} & =\text { Ramalan untuk priode waktu ke } t \\
n & =\text { Banyaknya data }
\end{aligned}
$$

Suatu metode mempunyai kemampuan peramalan sangat baik jika nilai MAPE kurang dari 10\%, mempunyai kemampuan peramalan baik jika nilai MAPE berada diantara $10 \%$ sampai $20 \%$ dan mempunyai kemampuan peramalan cukup jika nilai MAPE berada diantara 20\% sampai 50\%, sedangkan berkemampuan buruk jika nilai MAPE lebih dari 50\% [5].

\section{DATA}

Penelitian ini menggunakan data bulanan wisatawan asing di Kalimantan Barat dari bulan Januari 2014 sampai bulan Desember 2017 melalui pos lintas batas Entikong. Data wisatawan asing di Kalimantan Barat disajikan pada Tabel 1.

Tabel 1. Data Wisatawan Asing di Kalimantan Barat

\begin{tabular}{lllll}
\hline \multirow{2}{*}{ Bulan } & \multicolumn{4}{c}{ Tahun } \\
\cline { 2 - 5 } & $\mathbf{2 0 1 4}$ & $\mathbf{2 0 1 5}$ & $\mathbf{2 0 1 6}$ & $\mathbf{2 0 1 7}$ \\
\hline Januari & 1.535 & 1.265 & 1.050 & 2.508 \\
Februari & 1.609 & 1.873 & 2.307 & 1.525 \\
Maret & 1.699 & 2.440 & 1.937 & 2.626 \\
April & 1.430 & 1.491 & 1.426 & 1.689 \\
Mei & 1.785 & 2.424 & 2.046 & 2.003 \\
Juni & 1.703 & 1.662 & 1.515 & 2.040 \\
Juli & 2.488 & 2.573 & 2.360 & 1.081 \\
Augustus & 1.568 & 1.710 & 2.319 & 1.564 \\
September & 1.445 & 1.693 & 2.148 & 2.205 \\
Oktober & 1.731 & 1.455 & 1.494 & 1.123 \\
November & 1.936 & 2.513 & 1.610 & 1.078 \\
Desember & 3.535 & 3.753 & 3.433 & 2.792 \\
\hline
\end{tabular}

Berdasarkan Tabel 1 menunjukkan bahwa data jumlah wisatawan asing di Kalimantan Barat mengalami peningkatan dan penurunan setiap bulannya. Kunjungan wisatawan asing tertinggi terjadi pada bulan Desember 2015, sedangkan wisatawan asing terendah terjadi pada Januari 2016. Bentuk pola data jumlah wisatawan asing di Kalimantan Barat disajikan pada Gambar 1.

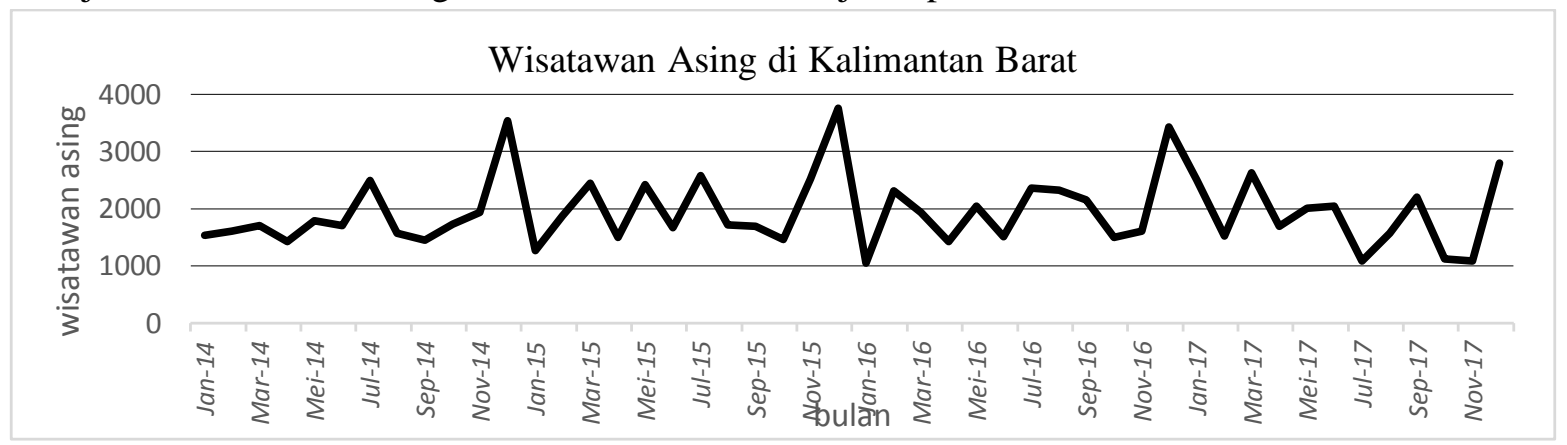

Gambar 1. Pola Data Wisatawan Asing di Kalimantan Barat 
Gambar 1 menunjukkan bahwa pola data jumlah wisatawan asing di Kalimantan Barat mengalami penurunan dan peningkatan setiap bulan. Namun pada gambar tersebut terlihat bahwa peningkatan jumlah wisatawan asing terjadi pada bulan Desember dan penurunan pada bulan Januari setiap tahunnya. Peningkatan dan penurunan pada data tersebut mengidentifikasikan bahwa data wisatawan asing di Kalimantan Barat berpola musiman.

\section{PERAMALAN METODE WINTER ADITIF}

Langkah pertama yang dilakukan dalam peramalan dengan metode pemulusan eksponensial Winter Aditif adalah menetapan nilai parameter $(\alpha, \beta$ dan $\gamma)$. nilai parameter yang digunakan pada penelitian ini adalah $\alpha=0,11, \beta=0,01$ dan $\gamma=0,91$ dimana nilai tersebut merupakan nilai parameter terbaik berdasarkan nilai MAPE yang paling kecil dengan bantuan Software Zaitun Time series.

Setelah ditetapkan nilai parameter terbaik, maka selanjutnya nilai awal pemulusan menggunakan Persamaan (5), (6) dan (7). Hasil perhitungannya adalah sebagai berikut.

Untuk $L=12$, diperoleh

$$
\begin{aligned}
& S_{L}=\frac{1}{12}(1535+1609+\cdots+3535)=1.872 \\
& b_{L}=\frac{1}{12}\left(\frac{1.365-1.535}{12}+\frac{1.873-1.609}{12}+\cdots+\frac{3.753-3.535}{12}=-16,58\right. \\
& I_{k}=X_{k}-S_{L}
\end{aligned}
$$

Dimana $k=1,2,3, \ldots \mathrm{L}$

$$
\begin{gathered}
I_{1}=1.535-1.872=-337 \\
I_{2}=1.609-1.872=-263 \\
I_{3}=1.699-1.872=-173 \\
I_{4}=1.430-1.872=-443 \\
\quad \vdots \\
I_{12}=3.535-1.872=1663
\end{gathered}
$$

Setelah nilai awal pemulusan diperoleh, maka selanjutnya menghitung pemulusan keseluruhan menggunakan Persamaan (1), sehingga hasil perhitungannya adalah sebagai berikut:

Untuk $t=13$,

$$
S_{13}=0,11(1265-(-337))+(1-0,11)(1872+(-16,58)=1.827,54
$$

Untuk $t=14$

$$
S_{14}=0,11(1873-(-263))+(1-0,11)(1.827,54+(-15,97))=1.847,25
$$

Untuk $t=14,15, \ldots, 48$ dihitung dengan cara seperti diatas.

Langkah selanjutnya menghitung pemulusan trend menggunakan Persamaan (2), sehingga hasil perhitungannya adalah sebagai berikut:

Untuk $t=13$

Untuk $t=14$

$$
b_{13}=0,01((1.827,54-1.872)+(1-0,01)(-16,58)=-15,97
$$

$$
b_{14}=0,01(1.847,54-1.827,54)+(1-0,01)(-15,97)=-16,01
$$

Untuk $t=15,16, \ldots, 48$ dihitung dengan cara seperti diatas.

Langkah selanjutnya menghitung pemulusan musiman menggunakan Persamaan (3), sehingga hasil perhitungannya adalah sebagai berikut: 
Untuk $t=13$

Untuk $t=14$

$$
I_{13}=0,91(1265-1.827,54)+(1-0,91)-16,58=-542,24
$$

$$
I_{14}=0,91(1.873-1.847,25)+(1-0,91)-542,24=0,24
$$

Untuk $t=15,16, \ldots, 48$ dihitung dengan cara seperti diatas.

Setelah diperoleh nilai pemulusan keseluruhan, trend dan musiman, selanjutnya menghitung ramalan menggunakan Persamaan (4), sehingga hasil perhitungannya sebagai berikut.

Untuk ramalan ke 14

$$
F_{13+1}=1.827,54+(-15,97)(1)+(-263)=1.638,56
$$

Untuk ramalan ke 15

$$
F_{14+1}=1.847,25+(-16,01)(1)+(-173)=1.658,24
$$

Untuk ramalan ke 48

$$
F_{47+1}=1.732,60+(-13,26)(1)+1607,32=3.329,89
$$

Setelah menghitung ramalan, didapat bentuk model ramalan. Bentuk ramalannya adalah sebagai berikut

$$
F_{48+m}=1.945,94+5,97256(m)+I_{48-12+m}
$$

\section{AKURASI PERAMALAN}

Setelah dilakukan perhitungan ramalan menggunakan metode pemulusan eksponensial Winter Aditif, kemudian dari hasil ramalan tersebut dihitung akurasi ramalannya menggunakan Persamaan (8), sehingga diperoleh nilai MAPE sebesar 26,09\%. Berdasarkan nilai MAPE tesebut, menunjukkan bahwa metode pemulusan eksponensial Winter Aditif memiliki rata-rata akurasi ramalan yang cukup baik dalam memperkirakan ramalan jumlah wisatawan asing di Kalimantan Barat. Untuk lebih jelasnya perbandingan hasil ramalan dapat dilihat pada Gambar 2 berikut.

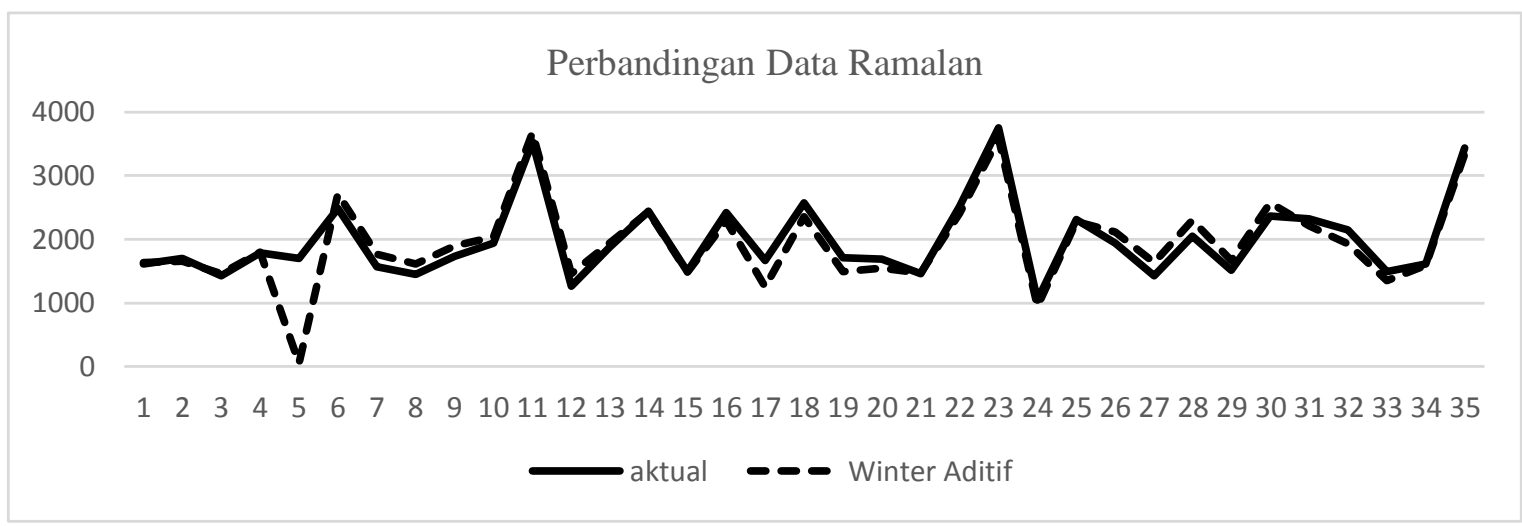

Gambar 2. Perbandingan Data Ramalan

Berdasarkan Gambar 2 terlihat bahwa hasil ramalan metode pemulusan eksponensial Winter Aditif mengikuti pola data aktual, sehingga metode tersebut dapat digunakan dalam memperkirakan jumlah wisatawan asing di Kalimantan Barat pada tahun 2018.

\section{PERKIRAAN WISATAWAN ASING DI KALIMANTAN BARAT}

Dalam memperkirakan jumlah wisatawan asing di Kalimantan Barat pada tahun 2018 dilakukan menggunakan Persamaan (9), sehingga diperoleh hasil seperti berikut. 
Tabel 3. Hasil Perkiraan wisatawan asing di Kalbar

\begin{tabular}{cccc}
\hline Bulan & Wisatawan Asing (orang) & Bulan & Wisatawan Asing(orang) \\
\hline Januari & 2.439 & Juli & 1.275 \\
Febuari & 1.574 & Agustus & 1.759 \\
Maret & 1.548 & September & 2.310 \\
April & 1.598 & Oktober & 1.274 \\
Mei & 1.975 & November & 1.307 \\
Juni & 1.918 & Desember & 2.711 \\
\hline
\end{tabular}

Berdasarkan Tabel 3 dapat dilihat bahwa hasil perkiraan jumlah wisatawan asing di Kalimantan Barat mengalami fluktuasi setiap bulannya. Namun terlihat bahwa wisatawan asing terendah terjadi pada bulan Oktober sebesar 1.274 orang. Sedangkan wisatawan asing tertinggi terjadi pada bulan Desember mencapai 2.711 orang.

\section{KESIMPULAN}

Berdasarkan hasil perhitungan diperoleh bahwa:

1. Metode pemulusan eksponensial Winter Aditif dengan $\alpha=0,11, \beta=0,01$ dan $\gamma=0,91$ nilai MAPE sebesar 26,09\%. Berdasarkan nilai MAPE tersebut menujukkan bahwa metode pemulusan eksponensial Winter Aditif memiliki kemampuan peramalan yang cukup baik, sehingga dapat digunakan dalam memperkirakan jumlah wisatawan asing di Kalimantan Barat pada tahun 2018.

2. Berdasarkan perhitungan dengan Metode pemulusan eksponensial Winter Aditif diperoleh bentuk model peramalannya adalah $F_{48+m}=1945,94+5,97256(m)+I_{48-12+m}$

3. Berdasarkan hasil perkiraan jumlah wisatawan asing di Kalimantan Barat pada Januari 2018 sampai Desember 2018 dengan menggunakan metode pemulusan eksponensial Winter Aditif, diperoleh jumlah wisatawan asing terendah pada bulan Oktober sebesar 1.274 orang dan yang tertinggi terjadi pada bulan Desember mencapai 2.711 orang.

\section{DAFTAR PUSTAKA}

[1]. Martin JN dan Nakayama TK. Intercultural Communication in Contexts. New York: McGrawHill 2009.

[2]. Heizer, Jay dan Render. Manajemen Operasi. Jakarta: Salemba Empat; 2001.

[3]. Subagyo P. Forecasting Konsep dan Aplikasi. Yoyakarta: BPFE; 1986.

[4]. Makridakis S, Wheelwright SC dan McGee VE. Metode dan aflikasi peramalan edisi 2. [U. U.S.Andriyanto dan A. Basith trans]. Jakarta: Erlangga; 1988.

[5]. Chang PC, Wang YW dan Liu CH. The Development of a Weighted Evolving Fuzzy Neural Network for PCB Sales Forecasting. Journal Expert Systems with Applications. 2007; 32:86-96.

[6]. Badan Pusat Statistik, Kalimantan Barat Dalam Angka 2014-1017.Pontianak:BPS.2014-2017

MELITA

: Jurusan Matematika FMIPA UNTAN, Pontianak, Melitameli008@gmail.com 